Tajdid: Jurnal Pemikiran Keislaman dan Kemanusiaan

Vol. 4 No. 2 Oktober 2020

\title{
ANALISIS PENERAPAN PASAL 18 UNDANG-UNDANG DASAR NEGARA REPUBLIK INDONESIA 1945 TERHADAP PELAKSANAAN PEMERNTAHAN DAERAH
}

\author{
Aman Ma'arij \\ STIH Muhammadiyah Bima \\ Email: ma’arijstihbima@gmail.com
}

\begin{abstract}
Abstrak:
Pelaksanaan sistem otonomi dalam penyelenggaraan pemerintah daerah sejauh ini yang menonjol hanya sebatas tentang pemilihan kepala daerah secara langsung setiap daerah-daerah dalam rangka mengembalikan kedaulatan ke tangan rakyat, sesuai dengan tuntutan reformasi dan amandemen Undang-Undang Dasar Negara Republik Indonesia Tahun 1945. Berdasarkan Undang-Undang Nomor 23 Tahun 2014 tentang Pemerintahan Daerah telah diatur tentang pemilihan kepala daerah dan wakil kepala daerah, mulai dari pasal 65 sampai dengan pasal 118, kepala daerah dan wakil kepala daerah dipilih dalam satu pasangan calon yang dilaksanakan secara demokratis berdasarkan asas langsung, umum, bebas, rahasia, jujur dan adil yang diajukan oleh partai politik atau gabungan partai politik. Sistem otonomi dalam penyelenggaraan pemerintahan daerah sudah seuai dengan pasal 18, dengan pemberian wewenang penuh kepala daerahdaerah otonom maka kemajuan disetiap daerah akan tercapai tanpa ada intervensi dari pemerintah pusat dengan perimbangan keuangan yang diatur oleh pemerintahan pusat secara proporsional.
\end{abstract}

Kata Kunci: Sistim Pemerintahan Daerah, Pasal 18, UUD 1945.

\section{Pendahuluan}

$\mathrm{P}$ emberlakuan Undang-Undang Nomor 23 Tahun 2014 tentang Pemerintah Daerah sebagai pengganti Undang-Undang Nomor 32 Tahun 2004 telah membawa dampak yang signifikan bagi sistem ketatanegaraan di Indonesia. Sistem pemerintahan di Indonesia meliputi tiga hal yakni, Pemerintahan Pusat dalam hal ini pemerintah, Pemerintahan Daerah yang meliputi pemerintahan Pronpinsi dan pemerintahan Kabupaten/Kota, serta Pemerintahan Desa. Ketiga subsatnasi tersebut saling berhubungan dengan satu sistem garis pemerintahan. Namun masing-masing mempunyai wewenang dan kekuasaan yang diatur lebih spesifik dalam Undang-Undang.

Presiden adalah memegang kekuasaan pemerintahan Negara atau pemerintahan pusat sedangkan Gubernur dan Bupati/Walikota adalah pemegang kekuasaan pemerintahan daerah. Berdasarkan ajaran trias politica oleh 
Tajdid: Jurnal Pemikiran Keislaman dan Kemanusiaan

Montesqui", "bahwa kekuasaan pemerintah dipisahkan menjadi kekuasaan eksekutif, kekuasaan legislatif dan kekuasaan yudikatif'. Sistem pemerintahan di Indonesia tidak menegnal istilah pemisahan kekuasaan namun terjadi pembagian kekuasaan yang meliputi kekuasaan menjalankan fungsi pemerintahan dalam arti kekuasan eksekutif dilakukan oelh Presiden berserta MenteriMenterinya. Kekuasaan membuat Undang-Undang atau legislatif dilakukan oleh Dewan Perwakilan Rakyat (DPR), dan kekuasaan yudikatif atau bidang peradilan dilakukan oleh Mahkamah Agung (MA).

Di dalam Undang-Undang Nomor 23 Tahun 2014 tentang Pemerintahan Daerah, hubungan dengan fungsi pemerintah pusat dan pemerintah daerah dilaksanakan melalui sistem otonomi yang meliputi disentralisasi, dekonsentrasi dan tugas pembantuan. Hubungan ini bersifat koordinatif administratif, artinya hakekat fungsi pemerintahan tersebu tidak ada yang saling membawahi, namun demikian fungsi dan peran pemerintah propinsi yang mengemban tugas sebagai wakil pemerintah pusat di daerah (dekonsentrasi). Tugas-tugas yang diberikan oleh pemerintah pusat selanjutnya dikoordinasikan di daerah setempat dimana di dalam propinsi terdapat pemerintahan daerah seperti Kabupaten/Kota bahkan pemerintahan desa yang merupakan struktur sistem pemerintahan yang terbawah.

Operasional dari pengertian otonomi mencakup dua komponen utama yaitu, yang pertama komponen menetapkan dan melaksanakan kebijakan berbagai komponen yang mengacu pada konsep pemerintahan yang terdapat dalam pengertian otonomi dan yang kedua, kemandirian sebagai komponen yang mengacu pada kata-kata oleh, dari dan untuk rakyat sebagaimana yang diamanatkan dalam konstitusi Negara Kesatuan Republik Indonesia yaitu Undang-Undang Dasar 1945. Kedua landasan tersebut merupakan landasan fundamental dalam pembentukan pemerintahan daerah sesuai dengan amanat pasal 18 Undang-Undang Dasar 1945, telah menciptakan berbagai produk Undang-Undang dan peraturan perundang-undangan lainnya yang mengatur tentang pemerintahan daerah antara lain Undang-Undang Nomor 7 Tahun 1957, Undang-Undang Nomor 18 Tahun 1965, Undang-Undang Nomor 5 Tahun 1974, Undang-Undang Nomor 32 Tahun 2004 dan dalam periode terakhir adalah Undang-Undang Nomor 23 Tahun 2014.

Secara substansial Undang-Undang yang disebutkan diatas mengatur tentang bentuk susunan penyelenggaraan daerah. Secara normatif UndangUndang tersebut telah mampu mengikuti perkembangan perubahan pemerintah daerah sesuai dengan zamannya. Secara empiris Undang-Undang tersebut dalam penyelenggaran pemerintahan daerah sebelum diberlakukannya Undang-Undang

${ }^{1}$ Siswanto Sunarno, Hukum Pemerintahan Daerah di Indonesia (Jakarta: Sinar Grafika, Jakarta, 2006), 5 
Tajdid: Jurnal Pemikiran Keislaman dan Kemanusiaan

Nomor 22 Tahun 1999 yakni Undang-Undang Nomor 23 Tahun 2014 dimana Undang-Undang Nomor 5 Tahun 1974 dan Undang-Undang sebelumnya memberikan implikasi terhadap kedudukan dan peran formal eksekutif yang lebih dominan dari legislatif daerah.

Undang-Undang Nomor 5 Tahun 1974 dan Undang-Undang sebelumnya, kedudukan kepala daerah sebagai eksekutif memiliki kewenangan yang lebih besar dari pada kekuasaan Dewan Perwakilan Rakyat Daerah (DPRD) sebagai pelaksana kekuasaan legislatif. Secara ekstrim dapat dikatakan bahwa kepala daerah tidak dapat diberhentikan secara langsung oleh Dewan Perwakilan Rakyat Daerah (DPRD) dan dalam pelaksanaan tugasnya hanya memberikan keterangan pertanggungjawaban. Berbeda dengan Undang-Undang Nomor 23 Tahun 2014, Undang-Undang ini menjawab tuntutan reformasi dengan penyelenggaraan pemerintah menggunakan format otonomi seluas-luasnya. Hubungan antara fungsi pemerintahan di daerah tidak saling membawahi dan saling terikat pada hubungan koordinatif administratif. Dalam penyelenggaraan pemerintahan daerah, DPRD adalah unsur penyelenggara pemerintah daerah disamping kepala daerah. Dengan kata lain, bahwa fungsi dan peran kepala daerah, perangkat daerah dan DPRD dalam penyelenggaraan pemerintah daerah kedudukannya tidak saling membawahi, namun dalam sistem kemitraan.

\section{Metode Penelitian}

Sebagai usaha untuk mendekati kesempurnaan di dalam penelitian ini, Penulis akan menggunakan jenis penelitian "Normatif" yaitu dengan menggunakan data Sekunder. Penelitian Hukum Normatif yaitu Penelitian dilakukan terhadap peraturan perundang-undangan dan norma-norma positif dalam sistem perundang-undangan yang berkaitan dengan permasalahan Skripsi ini. $^{2}$. Dalam penelitian ini, pendekatan penelitian yang digunakan adalah sebagai berikut : 1) Pendekatan Perundang-undangan (statute approach), yaitu merupakan pendekatan yang digunakan untuk mengkaji dan menganalisis peraturan perundang-undangan dan pengaturan yang bersangkut paut dengan isu hukum yang sedang ditangani. 2) Pendekatan Konseptual (conceptual approach) yaitu pendekatan yang di lakukan dengan mengkaji konsep-konsep, teori-teori dan pendapat para ahli yang ada kaitannya dengan objek yang di teliti. 3) Pendekatan Analisis (analytical approach), yaitu pendekatan yang dilakukan dengan cara menganalisis bahan-bahan hukum. ${ }^{3}$

\footnotetext{
${ }^{2}$ Salim HS Dan Erlies Septiana Nurbaini, Penerapan Teori Hukum Pada Penelitian Tesis Dan Disertasi (Cet. 2; Jakarta: Rajawali Pers, 2013), 20

${ }^{3}$ Salim HS Dan Erlies Septiana Nurbaini...,23
} 
Tajdid: Jurnal Pemikiran Keislaman dan Kemanusiaan

Vol. 4 No. 2 Oktober 2020

\section{Tinjauan Teoritis}

1. Pengertian Sistim Pemerintahan Daerah Menurut Teori

Istilah "pembagian kekuasaan" berarti bahwa kekuasaan itu memang dibagi-bagi dalam beberapa bagian, tapi tidak dipisahkan. Hal ini membawa konsekwensi bahwa diantara bagian-bagian itu dimungkinkan adanya kerjasama. ${ }^{4}$ Para pendiri negara telah menunjukan dasar dan sendi-sendi sistem pemerintahan negara menurut Undang-Undang Dasar 1945. Indonesia adalah negara hukum, salah satu unsur negara hukum adalah pemabagian kekuasaan dalam negara dimana ada empat unsur penting dari negara hukum Indonesia sebagai berikut:

a. Pemerintahan (dalam arti luas) dalam melaksanakan tugas kewajibannya harus berdasarkan hukum baik tertulis maupun yang tidak tertulis;

b. Adanya jaminan terhadap hak-hak asasi manusia (dan warganya);

c. Adanya pengawasan peradilan (oleh badan-badan perwakilan);

d. Adanya pembagian kekuasaan (distribution of power) dalam negara.

2. Pengertian Sistem Pemerintahan Daerah Menurut Undang-Undang Dasar 1945

Negara Republik Indonesia sebagai Negara kesatuan menganut asas Desentralisasi dalam penyelenggaraan pemerintahan, dengan memberikan kesempatan dan keleluasan kepada Daerah untuk menyelenggarakan Otonomi Daerah dalam Pasal 18 Undang Undang Dasar 1945 dinyatakan bahwa : "Sistem pemerintahan daerah di Indonesia menurut Konstitusi Undang Undang Dasar 1945 berdasarkan penjelasan dinyatakan bahwa daerah Indonesia akan dibagi dalam daerah provinsi dan daerah provinsi akan dibagi pula dalam daerah yang lebih kecil".

\section{Asas-Asas Pemerintahan Daerah}

Dalam hal pelimpahan wewenang dari pemerintah pusat kepada daerah guna penyelenggaraan pemerintahan daerah dalam pelaksanaan otonomi daerah, di daerah dikenal adanya tiga asas penyelenggaraan pemerintahan daerah yaitu asas dekonsentrasi, asas desentralisasi, dan asas tugas pembantuan.

${ }^{4}$ Bagir Manan, Menyongsong Fajar Otonomi Daerah (Yogyakarta: Pusat Studi Hukum (PSH) Fakultas Hukum UII, 2000), 23 
Tajdid: Jurnal Pemikiran Keislaman dan Kemanusiaan

Vol. 4 No. 2 Oktober 2020

4. Penyelenggaraan Pemerintahan Daerah

Penyelenggaraan pemerintahan daerah adalah Dewan Perwakilan rakyat Daerah (DPRD) sebagai badan legislatif daerah dan pemerintah daerah yang terdiri atas kepala daerah sebagai badan eksekutif daerah serta perangkat daerah lainnya.

\section{Hasil Penelitian}

\section{Tinjauan Sistem Pemerintahan Daerah Menurut Pasal 18 Undang-Undang Dasar 1945}

Rumusan pasal 18 sebelum Amandemen Undang-Undang Dasar Negara Republik Indonesia Tahun 1945 mempunyai latar belakang yang dapat diketahui dari catatan (Notulen) sidang PPKI pada tanggal 18 Agustus 1945 M. Amin seklaku anggota PPKI menyatakan supaya pemerintah Republik Indonesia disusun dengan sedemikian rupa sehingga diadakan desentralisasi dan dekonsentalisasi sebesar-besarnya pulau-pulau supaya dibentuk pemerintahan agar rakyat berhak mengurus rumah tangganya sendiri dengan seluas-luasnya. ${ }^{5}$ Selain itu anggota PPKI Ratulangie menyatakan antara lain perkataan dekonsentrasi dan desentralisasi artinya supaya seluas-luasnya untuk mengurus keperluannya menurut pikirannya sendiri, menurut kehendaknya sendiri, tentu dengan memakai persetujuan bahwa daerah-daerah itu adalah daerah daripada Indonesia dan satu Negara. ${ }^{6}$

Istilah yang seluas-luasnya pada pengertian otonomi adalah tidak tepat karena pengertiannya cenderung tidak terbatas padahal yang dimaksud adalah otonomi dalam rangka Negara Kesatuan Republik Indonesia. seperti halnya pendapat Bagir Manan bahwa setiap Negara kesatuan dapat disusun dan diselenggrakan berdasarkan asas dan sistem sentralisasi atau desentralisasi. Desentralisasi akan di dapat apabila urusan mengatur urusan penyelenggaran pemerintah tidak semata-mata dilakukan oleh satuan-satuan pemerintahan tingkat lebih rendah yang mandiri (Jelstanding) bersifat otonom (territorial atau fungsional). ${ }^{7}$ Sejarah pengaturan berdasarkan prinsip Negara Kesatuan Republik Indonesia, dalam konstitusi yang berlaku senantiasa terdapat ketentuan tentang Negara kesatuan ytang berkaitan dengan prinsip desentralisasi, demikian pula dalam Undang-Undang Dasar Negara Republik Indonesia Tahun 1945 termasuk pengaturan setelah Amandemen pertama sampai dengan amandemen keempat terhadap konstitusi tersebut, yang berlaku hingga masa reformasi sekarang ini.

\footnotetext{
${ }^{5}$ Arif Mujadhi, Landasan dan Prinsip Hukum Otonomi Daerah Dalam Negara Kesatuan RI (Jakarta: Prestasi Pustaka, 2005), 34

${ }^{6}$ Ibid.

${ }^{7}$ Bagir Manan, 2001, Menyongsong Fajar Otonomi Daerah, (Yogyarkarta: Pusat Studi Hukum (PSH), Fakultas Hukum UI, 2001), 147
} 
Tajdid: Jurnal Pemikiran Keislaman dan Kemanusiaan

Sebelum berlaku Undang-Undang Nomor 22 Tahun 1999 tentang pemerintahan Daerah (termasuk juga pemerintahan Desa) dan kemudian digantikan dengan Undang-Undang Nomor 23 Tahun 2014 tentang Pemerintahan daerah (termasuk juga Pemerintahan Desa) yang berlaku mulai tanggal 15 Oktober 2004 maka berdasarkan Undang-Undang Dasar Negara Republik Indonesia Tahun 1945 sejak Tahun 1945 sampai saat ini telah pernah berlaku dan sedang berlaku peraturan atau Undang-Undang tentang penyelenggaraan pemerintahan daerah atau otonomi daerah.Disamping pemerintahan nasional atau pemerintahan Pusat yakni mulai Undang-Undang Nomor 1 Tahun 1945 tentang Komite Nasional Daerah sampai Undang-Undang Nomor 5 Tahun 1974 tentang Pokok-Pokok Pemerintahan di daerah, dan Undang-Undang Nomor 5 Tahun 1979 tentang Pemerintahan Desa, serta kemudian Undang-Undang Nomor 22 Tahun 1999 tentang pemerintahan daerah yang telah dicabut atau tidak berlaku sejak tanggal 15 Oktober 2004 dan sejak saat itu berlaku Undang-Undang Nomor 23 Tahun 2014 tentang pemerintahan daerah yang berlaku hingga sekarang. Berbagai Undang-Undang dan peraturan tentang pemerintahan daerah tersebut dimaksud pada dasarnya dilandasi aturan dasar dalam Undang-Undang Dasar yang berlaku selama masa tersebut dalam, dalam hal ini Undang-Undang Dasar Negara Republik Indonesia yang dilandasi prinsip dan asas Negara kesatuan dan prinsip desentralisasi.

Sejarah perkembangan pengaturan tentang pelaksanaan desentralisasi atau otonomi daerah di Indonesia, terutama sejak kemerdekaan yakni tahun 1945 sampai masa berlaku Undang-Undang Nomor 5 Tahun 1974 tentang PokokPokok Pemerintahan di daerah, dan Undang-Undang Nomor 22 Tahun 1999 tentang Pemerintahan Daerah, ternyata telah dialami berbagai pengaturan yang tidak konsisten yakni telah terkjadi beberapa kali perubahan secara prinsip pengaturan tentang pelaksanaan desentralisasi atau otonomi daerah sehingga dalam kenyataan di Indonesia memang belum pernah terjadi penyelenggaraan pemerintahan local (Pemerintahan Daerah) yang relative kuat.

Hal-hal ini pula yang menjadi hambatan pelaksanaan berbagai pengaturan tentang desentralisasi atau otonomi daerah pada masa berlakunya Undang-Undang Nomor 5 Tahun 1974 yang mana berakhir pada tanggal 7 Mei 1999. Pembentukan Undang-Undang Nomor 5 Tahun 1974 tersebut, menghendaki otonomi daerah dilaksanakan dengan titik berat otonomi pada daerah tingkat II, dan prinsip titik berat otonomi pada daerah tingkat II dimaksud tertuang dalam pasal 11 UndangUndang Nomor 5 Tahun 1974 dengan penjelasan bahwa hal titik berat otonomi itu dalam rangka peningkatan pelayanan pada masyarakat dan pelaksanaan pembangunan. Dan dengan alasan bahwa daerah tingkat II lebih bisa berhubungan dengan masyarakat sehingga akan lebih bisa mengerti dalam memenuhi harapan masyarakat yang dimaksud. Prinsip otonomi daerah dengan titik berat otonomi 
Tajdid: Jurnal Pemikiran Keislaman dan Kemanusiaan

pada daerah tingkat II waktu itu, dimaksud oleh pembentuk Undang-Undang sebagai bagian dari penjabaran prinsip otonomi daerah yang nyata adan bertanggungjawab atau otonomi daerah yang nyata, dinamis, serasi dengan tanggungjawab.

Ketentuan pasal 11 Undang-Undang Nomor 5 Tahun 1974 tersebut mengandung banyak hambatan utnuk dilaksanakan, karena mengandung permasalahan antara lain menyangkut dan berkaitan dengan aspek pengurangan jumlah dan jenis urusan pemerintahan pusat dam urusan pemerintahan daerah tingkat I, serta pengurangan urusan dan jenis urusan kegiatan instansi vertikal (pusat dan daerah Tingkat I) disetiap daerah tingkat II sehingga ketentuan pasal tersebut tidak dapat diterapkan dalam waktu yang singkat setelah undang-undang tersebut berlaku. Sepanjang masa berlakunya Undang-Undang Nomor 22 Tahun 1999 tentang Pemerintahan Daerah mulai tanggal 7 Mei 1999 sampai saat akan diganti Undang-Undang Nomor 23 Tahun 2014 tentang Pemerintahan Daerah, telah muncul berbagai problematika dari keberlakuan Undang-Undang Nomor 22 Tahun 1999.

Selanjutnya dasar pertimbangan Undang-Undang Nomor 22 Tahun 1999 disebabkan oleh dua factor yakni: 1). Perubahan pengaturan ketatanegaraan terutama setelag di Amandemenya Undang-Undang Dasar Negara Republik Indonesia Tahun 1945 serta diundangkannya berbagai peraturan perundangundangan baru dalam bidang politik yakni Undang-Undang Nomor 31 Tahun 2002 tentang Partai Politik, Undang-Undang Nomor 12 Tahun 2003 tentang, Undang-Undang Nomor 1 Tahun 2004 tentang perbendaharaan Negara, UndangUndang Nomor 15 Tahun 2004 tentang pemeriksaan, pengelolaan dan tanggungjawab keuangan Negara; dan 2). alasan lainnya yaitu penyelesaian berbagai persoalan dalam perjalanan dalam tiga Tahun seperti: issu pembagian kewenagan antara tingkat pemerintahan yang belum jelas kriterianya, hunungan antara Propinsi dan Kabupaten/Kota, issu kepegawaian yang menimbulkan ego kedaerahan dan sulitnya mutasi Pegawai Negeri Sipil (PNS), issu pemilihan kepala daerah yang ditegarai sarat konflik dan praktek politik unag dan issu pemerintahan desa yang melahirkan ragam konflik misalkan antara kepala desa dan BPD, pemekaran wilayah desa dan sebagainya. Mencermati berbagai alasan diatas sangat masuk akal dan memadai pentingnya diadakan perubahan.

Semenjak dilaksanakan Undang-Undang Nomor 22 Tahun 1999 telah menimbulkan banyak perubahan yang cukup signifikan terhadap penyelenggaraan pemerintahan di berbagai daerah di Negara Kesatuan Republik Indonesia ini. Perubahan ini tidak hanya terjadi di daerah saja, tetapi juga hubungan antara pemerintahan pusat dan daerah dalam hal hubungan kekuasaan. Sebelum diterbitkannya Undang-Undang tersebut, hubungan antara pemerintahan pusat dan daerah lebih bersifat sentralistis. Namun setelah berlakunya Undang-Undang 
Tajdid: Jurnal Pemikiran Keislaman dan Kemanusiaan

Nomor 22 Tahun 1999 tentang Pemerintahan Daerah, hubungan antara pemerintahan pusat dan daerah menjadi lebih bersifat desentralisasi, dalam arti sebagian wewenang di bidang pemerintahan diserahkan pada daerah untuk mengurusnya sendiri. Wewengan yang tetap dimiliki pemerintah pusat adalah wewenang dibidang politik luar negeri, pertahanan dan keamanan, peradilan, moneter dan fiskal, serta agama. Undang-Undang ini juga memberikan peluang kepada daerah-daerah yang memenuhi syarat dan memiliki potensi untuk dijadikan daerah otonom melalui pemekaran daerah sebagai perwujudan untuk mendorong peningkatan dan pemerataan kesejahteraan masyarakat.

Disamping itu peran Dewan Perwakilan Rakyat Daerah (DPRD) sebagai badan legislatif daerah yang sebelumnya ditempatkan sebagai bagian dari pemerintahan daerah, dalam Undang-Undang ini DPRD dipisahkan dari pemerintahan daerah dan dikembalikan kepada fungsi yang seharusnya sehinggga mempunyai kedudukan yang sederajat dengan pemerintahan daerah sebagai badan eksekutif daerah. Mengenai bidang keuangan, diatur perimbangan keuangan antara pemerintah pusat dan pemerintah daerah melalui UndangUndang Nomor 25 Tahun 1999. Namun, formula yang digunakan dalam UndangUndang ini tidak memuaskan sebagian besar daerah karena dalam pelaksanaannya, ternyata daerah yang kaya dan daerah yang miskin tetap miskin. Hal inilah jelas tidak akan menunjukan pemeraataan dalam kesejahteraan sebagaimana sesuai dengan tujuan pemberian otonomi itu sendiri. Bila hal ini tidak disikapi dengan arif dan bijaksana dengan membuat suatu aturan yang kebih adil yang dapat menunjukan pemerataan kesejahteraan masyarakat dikemudian hari, hal ini akan menimbulkan gejolak antar daerah yang pada gilirannya akan merusak keutuhan Negara Kesatuan Republik Indonesia.

Secara umum Undang-Undang Nomor 22 Tahun 1999 tentang pemerintahan daerah ini telah membawa kemajuan bagi daerah dan bagi peningkatan kesejahteraan bagi masyarakat karena pemerintah daerah diberi wewenang yang luas untuk mengelola kekayaan daerah guna dimanfaatkan bagi pembagunan daerah dan peningkatan kesejahteraan masyarakat di daerah. Namun, paradigm baru yang muncul bahwa Undang-Undang Nomor 22 Tahun 1999 dalam pelaksanaannya juga telah menimbulkan dampak yang negatif, antara lain tampilnya kepala daerah sebagai raja-raja kecil di daerah karena luasnya wewenang yang dimiliki, serta tidak jelasnya hubungan hirarkis dengan pemerintahan diatasnya. Disamping itu, dengan dimilikinya wewenang yang luas dalam pengelolaan keuangan dan kekayaan daerah terbuka peluang untuk tumbuhnya korupsi, kolusi dan nepotisme (KKN) di daerah-daerah yang akibantnya korupsi besar-besaran daerah daerah, baik dikalangan eksekutif maupun dikalangan legislatif serta lahirnya Perda-Perda tentang retribusi dan pajak daerah dan banyak hal lain yang bersifat negatif sebagai akibat pelaksanaan 
Tajdid: Jurnal Pemikiran Keislaman dan Kemanusiaan

Undang-Undang Nomor 22 Tahun 1999 seperti money politik yang terjadi dalam pemilihan kepala daerah, sengketa antar daerah, baik sengketa kewenangan maupun sengketa wilayah (perbatasan) dan lain sebagainya.

Beranjak dari hal tersebut diatas maka, perlu diadakan penyempurnaan Undang-Undang Nomor 22 Tahun 1999 tentang pemerintahan daerah dimana bertujuan untuk memperbaiki kelemahan-kelemahan yang terdapat dalam Undang-Undang tersebut, antara lain sebagaimana telah disebutkan diatas dan juga merupakan konsekwensi perubahan dalam tatanan kenegaraan akibat amandemen Undang-Undang Dasar Negara Republik Indonesia Tahun 1945 serta guna mengantisipasi arus globalisasi, terutama yang berkaitan dengan penanaman modal asing di daerah maka muncullah Undang-Undang Nomor 32 Tahun 2004tentang pemerintahan daerah (Lembaran Negara Republik Indonesai Tahun 2004 Nomor 125 dan Tambahan Lembaran Negara Republik Indonesia Nomor 4437) sebagai pengganti dari Undang-Undang Nomor 22 Tahun 1999 yang merupakan wujud penyempurnaan dari kelemahan-kelemahan yang sudah terjadi sebelumnya. Pada dasarnya ketentuan-ketentuan yang diatur dalam UndangUndang Nomor 23 Tahun 2014, sama dengan apa yang diatur dalam UndangUndang Nomor 22 Tahun 1999. Hanya pada Undang-Undang Nomor 32 Tahun 2004 lebih menjelaskan dan mempertegas hal-hal yang telah diatur dalam Undang-Undang Nomor 22 Tahun 1999 guna menutupi kelemahan-kelemahan dalam Undang-Undang Nomor 22 Tahun 1999 dimaksud, terutama mengenai hubungan antara pemerintah pusat dan pemerintah daerah, antara pemerintah propinsi dan pemerintah kabupaten/kota, antara sesama daerah kabupaten/kota sampai pada tingkat desa. Hubungan ini berkaitan dengan kesatuan administrasi dan kesatuan wilayah.

\section{Pelaksanaan Pemerintahan Daerah Menurut Undang-Undang Nomor 23 Tahun 2014 Tentang Pemeritahan Daerah}

1. Kekuasaan Pemerintahan Daerah Menurut Undang-Undang Nomor 23 Tahun 2014

Setiap Negara kesatuan (unitary state) dapat disusun dan diselenggarakan menurut asas dan sistem sentralisasi, dapat dilaksanakan oleh dan dari pusat pemerintahan (single sentralized government) atau oleh pusat bersama-sama organnya yang dipencarkan di daerah-daerahnya. Sentralisasi yang disertai dengan pemencaran organ-organ yang menjalankan sebagian wewenang pemerintahan pusat di daerah dikenal sebagai dekonsentrasi. Desentralisasi akan di dapat apabila kewengan mengatur dan mengurus penyelenggraan pemerintahan tidak semata-mata dilakukan oleh pemerintahan pusat (Central government), 
melainkan juga oleh kesatuan-kesatuan pemerintah yang rendah yang mandiri yang bersifat otonomi (teritorial ataupun fungsional). ${ }^{8}$

Menurut Undang-Undang Nomor 23 Tahun 2014, delam penyelenggaraan otonomi menggunakan format otonomi yang seluas-luasnya. Artinya, asas ini diberlakukan oleh pemerintah seperti pada era Undang-Undang Nomor 5 Tahun 1974. Alasan pertimbangan ini didasarkan suatu asumsi bahwa hal-hal mengenai urusan pemerintahan yang dapat dilaksanakan oleh daerah itu sendiri, sangat tepat diberikan kebijakan otonomi sehingga setiap daerah akan mampu dan mandiri dalam memberikan pelayanan dan untuk meningkatkan kesejahteraan rakyat di daerah. Hubungan antarafungsi pemerintahan ini tidak saling membawahi dan terikat pada hubungan koordinatif administrasi. Dalam penyelenggaraan pemerintahan daerah DPRD adalah unsur penyelenggara pemerintahan daerah disamping kepala daerah. Dengan kata lain, bahwa fungsi dan peran kepala daerah, perangkat daerah dan DPRD dalam penyelenggaraan pemerintahan daerah kedudukannya tidak saling membawahi, namun terikat dalam sistem kemitraan.

Pelaksaaan sistem otonomi dalam pemerintahan daerah sejauh ini yang menonjol hanya sebatas pemilihan kepala daerah secara langsung disetiap daerah dalam rangka mengembalikan kedaulatan ketangan rakyat,sesuai dengan tuntutan reformasi dan amandemen Undang-Undang Dasar Negara Republik Indonesia Tahun 1945. Berdasarkan Undang-Undang Nomor 23 Tahun 2014 telah diatur tentang pemilihan kepala daerah wakil kepala daerah, mulai dari pasal 65 sampai pasal 118. Kepala daerah dan wakil kepala daerah dipilih dalam satu pasangan calon yasng dilaksankan secara demokratis berdasarkan asas langsung, umum, bebas, rahasia, jujur dan adil yang diajukan oleh partai politik atau gabungan partai politik. Disamping itu dalam pelaksanaan pemerintahan daerah terdapat faktor pendukung yang menunjang kemajuan otonomi daerah yakni:

a. Daerah otonom diberikan kebebasan dalam arti untuk dapat mengurus rumah tangganya masing-masing sehingga pemgelolaan potendi daerah dapat dimanfaatkan untuk kemajuan daerahnya.

b. Bahwa dengan pemberian wewenang penuh kepada daerah otonom maka kemajuan disetiap daerah akan tercapai tanpa ada intervensi dari pemerintahan pusat dengan perimbangan keuangan yang diatur oleh pemerintah pusat secara proporsional.

Adapun mengenai faktor penghambat dalam pelaksanaan pemerintahan daerah bahwa Undang-Undang Nomor 23 Tahun 2014 masih belum menuangkan seluruh prinsip pengaturan baru sesuai hakekat sistem otonomi daerah terutama

${ }^{8}$ Nikmatul Huda, Otonomi Daerah; Filosofi, Sejarah Perkembangan dan Problematika (Yogyakarta: Pustaka Pelajar, 2005), 85 
Tajdid: Jurnal Pemikiran Keislaman dan Kemanusiaan

antara otonomi daerah propinsi dan otonomi daerah kabuapten/kota, antara lain aturan tentang penegasan hubungan dalam susunan bertingkat antara daerah propinsi dengan daerah kabupaten/kota.

2. Pemerintahan Desa

Pemerintahan Desa terdiri dari perangkat-perangkat sebagai berikut:

a. Kepala Desa

Kepala Desa dipilih langsung oleh dan dari penduduk desa. Seorang Kepala Desa haruslah seorang Warga Negara Republik Indonesia yang memenuhi syarat dan selanjutnya akan ditentukan dalam Peraturan daerah tentang Tata Cara Pemilihan Kepala Desa. Dala pemilihan Kepala Desa, calon yang memperoleh suara terbanyak ditetapkan sebagai Kepala Desa terpilih. Untuk desa yang memiliki hak tradisional yang masih hidup dan diakui kebenarannya, pemilihan kepala desa akan dilakukan sesuai dengan hukum adat setempat yang ditetapkan dalam Peraturan Daerah yang berpedoman pada Peraturan Pemerintah. Masa jabatan Kepala Desa adalah enam tahun dan dapat dipilih kembali hanya untuk satu kali masa jabatan berikutnya. Masa jabatan Kepala Desa bagi desa yang merupakan masyarakat hukum adat, yang keberadaannya masih hidup dan diakui, dapat dikecualikan dan hal ini diatur dalam Peraturan Daerah.

Kepala Desa terpilih dilantik oleh Bupati atau Walikota paling lambat tiga puluh hari (30) setelah calon yang bersangkutan dinyatakan sebagai calon terpilih. Sebelum memangku jabatannya, Kepala Desa mengucapkan sumpah atau janji sebagai berikut: “Demi Allah (Tuhan) saya bersumpah atau berjanji bahwa saya akan memenuhi kewajiban saya selaku Kepala Desa dengan sebaik-baiknya, sejujurnya dan seadilnya bahwa saya akan selalu taat dan mengamalkan Pancasila sebagai Dasar Negara, dan bahwa saya akan menegakkan kehidupan demokrasi dan Undang-Undang Dasar Negara Republik Indonesia Tahun 1945, serta melaksanakan segala peraturan perundang-undangan dengan selurus-lurusnya, yang berlaku bagi desa dan Negara Republik Indonesia”.

b. Perangkat Desa

Perangkat Desa terdiri dari sekertaris dan perangkat desa lainnya. Sekertaris desa di isi dari Pegawai Negeri Sipil (PNS) yang memenuhi persyaratan. Sementara itu sekertaris desa yang telaah ada sebelum berlakunya Undang-Undang Nomor 6 Tahun 2014 di isi oleh bukan Pegawai Negeri Sipil (PNS), namun secara bertahap diangkat menjadi Pegawai Negeri Sipil (PNS) sesuai dengan peraturan perundang-undangan yang berlaku. Urusan pemerintahan yang menjadi kewenagan pemerintahan desa mencakup; 1) Urusan pemerintahan yang sudah ada berdasarkan hak asal-usul desa. 2) Urusan pemerintahan yang menjadi kewenangan kabupaten/kota, yang diserahkan pengaturannya kepada desa. 3) Tugas pembatuan dari pemerintah pusat, pemerintah propinsi, dan atau 
Tajdid: Jurnal Pemikiran Keislaman dan Kemanusiaan

pemerinta kabupaten/kota. 4) Pemerintah kabupaten/kota, urusan pemerintahan lainnya yang oleh pengaturan perundang-undangan diserahkan kepada desa.

\section{c. Badan Permusyawaratan Desa}

Badan Permusyawaratan Desa, selanjutnya disebut BPD/Bamusdes, adalah suatu badan yang sebelumnya disebut Badan Perwakilan Desa, yang berfungsi menetapkan peraturan desa, bersama kepala desa, menampung dan menyalurkan aspirasi masyarakat. Anggota BPD adalah wakil dari penduduk desa yang bersangkutan, yang ditetapkan dengan cara musyawarah dan mufakat. Wakil yang dimaksud dalam hal ini adalah penduduk desa yang memangku jabatan seperti ketua rukun warga, pemangku adat dan tokoh masyarakat lainnya. Pimpinan BPD dipilih dari dan oleh anggota BPD. Masa jabatan BPD adalah enam tahun, sama dengan masa jabatan kepala desa, dan dapat dipilih kembali untuk satu kali masa jabatan berikutnya. Tata cara penetapan anggota dan pimpinan BPD diatur perda yang berpedoman pada peraturan pemerintah. Anggota BPD yang sudah ada pada saat berlakunya Undang-Undang Nomor 22 Tahun 1999 tetap menjalankan tugas sebagaimana diatur dalam Undang-Undang Nomor 6 Tahun 2014, sampai berakhirnya masa jabatan. Disamping BPD di desa dapat dibentuk lembaga lain, yang ditetapkan dengan peraturan desa dengan berpedoman pada peraturan perundang-undangan, berupa lembaga kemasyarakatan, seperti rukun tetangga, rukun warga, PKK, karang taruna, Lembaga Pemberdayaan Masyarakat (LPM). Lembaga kemasyarakatan ini bertugas membantu pemerintah desa, dalam upaya pemberdayaan masyarakat desa.

\section{Penutup}

Dari uraian yang telah disampaikan di depan maka dapat diambil simpulan bahwa pelaksanaan sistem otonomi dalam penyelenggaraan pemerintah daerah sejauh ini yang menonjol hanya sebatas tentang pemilihan kepala daerah secara langsung setiap daerah-daerah dalam rangka mengembalikan kedaulatan ke tangan rakyat, sesuai dengan tuntutan reformasi dan amandemen Undang-Undang Dasar Negara Republik Indonesia Tahun 1945. Berdasarkan Undang-Undang Nomor 23 Tahun 2014 tentang Pemerintahan Daerah telah diatur tentang pemilihan kepala daerah dan wakil kepala daerah, mulai dari pasal 65 sampai dengan pasal 118, kepala daerah dan wakil kepala daerah dipilih dalam satu pasangan calon yang dilaksanakan secara demokratis berdasarkan asas langsung, umum, bebas, rahasia, jujur dan adil yang diajukan oleh partai politik atau gabungan partai politik. Sistem otonomi dalam penyelenggaraan pemerintahan daerah sudah seuai dengan pasal 18, dengan pemberian wewenang penuh kepala daerah-daerah otonom maka kemajuan disetiap daerah akan tercapai tanpa ada intervensi dari pemerintah pusat dengan perimbangan keuangan yang diatur oleh pemerintahan pusat secara proporsional. 
Tajdid: Jurnal Pemikiran Keislaman dan Kemanusiaan

Vol. 4 No. 2 Oktober 2020

\section{DAFTAR PUSTAKA}

Abdullah, Rozali. Pelaksanaan Otonomi Luas dengan Pemilihan Kepala Daerah Secara Langsung. Jakarta: Rajawali Press, 2005.

Assidiqie, Jimly. Konstitusi dan Konstitusi Analisme Indonesia. Jakarrta: Kerjasama Mahkamah Agung dengan Pusat studi HTN UII, 2004.

Bratakusuma, Dedy Supriadi. 2004, Otonom Penyelenggaraan Pemerintah Daerah. Jakarta: Gramedia, 2004.

Juanda. Hukum Pemerintahan Daerah (Pasang Surut Hubungan Kewenangan Antara DPRD dan Kepala Daerah), Pt Alumni, Bandung, 2004.

Manan, Bagir. Menyongsong Fajar Otonomi Daerah. Yogyakarta: Pusat Studi Hukum (PSH) Fakultas Hukum UII, 2001.

Muljadi, Arif. Landasan dan Prinsip Hukum Otonomi Daerah Dalam Negara Kesatuan Republik Indonesia. Jakarta: Prestasi Pustaka, 2005.

Ni'matul Huda, Otonomi Daerah; Filosofi, Sejarah Perkembangan dan Problematika. Yogyakarta: Pustaka Pelajar, 2005.

Pipin Syarifin, Dedah Jubaidah. Pemerintahan Daerah di Indonesia. Bandung Pustaka Setia, 2006.

Sunarno, Siswanto. Hukum Pemerintahan Daerah Di Indonesia. Jakarta: Sinar Grafika, 2006.

Sunggono, Bambang. Metodelogi Penelitian Hukum. Jakarta: Rajawali Pers, 2003.

Syarkani, Afan Ghafar, M. Ryaas Rasyid. Otonomi Daerah Dalam Negara Kesatuan. Yogyakrta: Pustaka Pelajar Kerjasama deengan PUSKAP, 2003.

Undang-Undang Dasar Negara Republik Indonesia 1945.

Undang-Undang Nomor 22 Tahun 1999 Tentang Pemerintah Daerah.

Undang-Undang Nomor 23 Tahun 2014 Tentang Pemerintah Daerah.

Undang-Undang Nomor 32 Tahun 2004 Tentang Pemerintah Daerah.

Undang-Undang Nomor 5 Tahun 1974 Tentang Sentralistik. 